\title{
Para Eduardo Yázigi, amigo professor, uma homenagem
}

\author{
Everaldo Batista da Costa ${ }^{1}$
}

\section{(c) (i) $(5$ \\ DOI: https://doi.org/10.26512/patryter.v2i3.23281}

A segunda semana de fevereiro de 2019 iniciou mais triste, com a passagem do nobre amigo Eduardo Yázigi (janeiro e fevereiro do corrente ano inauguraram um período de muitos pesares).

Ao mesmo tempo, ameniza esse sentimento cortante da perda do corpo, parar para lembrar, ver, ler e reconhecer que Yázigi segue conosco, mais presente do que nunca, pois dedicou sua vida ao pensamento e, o que é fundamental, à prática do espaço vivido, percebido e concebido, com seu modo sempre inédito, criativo, provocador, provocante, erudito e sarcástico.

Brindou-nos com a revisão do "Espaço banal" (por último); divagou sobre o "Mundo das calçadas"; polemizou o "Turismo como esperança condicional"; questionou a "Alma do lugar"; analisou a "Civilização urbana" e, o que mais significa para mim a espiritualidade terrena e duradoura de Eduardo:

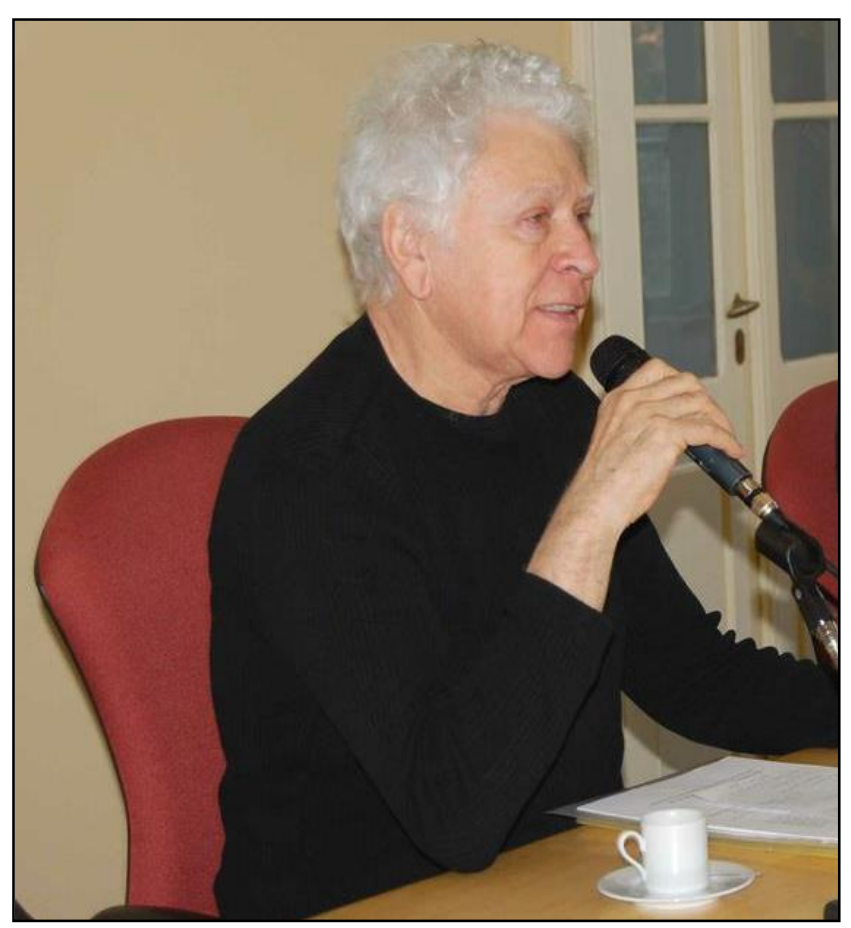

Eduardo Yázigi. Agosto de 2010, no Memorial do Ministério Público do Rio Grande do Sul, em Porto Alegre, Brasil; conferencia proferida na comemoração do dia Nacional do Patrimônio Histórico.

Fonte: https://www.mprs.mp.br/noticias/22102/ materializou suas "Saudades do futuro",

fazendo paródia e caricatura de sua própria imagem, nas "orelhas" do livro, ao apresentar sua foto de criança, na primeira, e sua caricatura "degenerada", na última, criativa e zombeteiramente. Esses livros de nosso amigo professor não são obras que se encerram em si e com ele, trazem sua angústia e astúcia permanentes, diante do descaso público com as cidades e com o território e, concomitantemente, nos obrigam a seguir a reflexão, em um fiel diálogo, pois sua escrita envolve e provoca o leitor.

Quem conhece e reconhece a obra e um pouco da longa e exultante vida de Eduardo Yázigi compreende bem o que digo; talvez, mais que eu, já que tive o privilégio de conviver com ele dezessete anos, ou desde que cheguei a Universidade de São Paulo, como estudante. Esse convívio se tornou mais rotineiro depois que defendi o doutorado. Ensaiamos, por duas vezes (2009 e 2018), organizar seminários; ocasiões em que fomos impedidos pela conhecida burocracia universitária. Outras vezes, o convidei para apresentar trabalhos a revistas da Universidade de Brasília, quando eu assumia o editorial das mesmas. Em 2013, nos enviou para a Revista Espaço

\footnotetext{
${ }^{1}$ Docente do Departamento de Geografia da Universidade de Brasília. Editor-Chefe da PatryTer. Email: everaldocosta@unb.br. ORCID: https://orcid.org/0000-0003-0734-6680.
} 
e Geografia o texto Patrimônio - patinho feio e enjeitado: sugestões metodológicas para a Geografia. ${ }^{2}$ Também foi o caso na Revista Cenário, na qual nos prestigiou, em 2016, com o texto O sentimento oceânico ${ }^{3}$. Por fim, em 2017 inauguramos a PatryTer e Yázigi foi convidado para o Conselho Científico. Em outubro de 2018, enviou seu primeiro artigo para a revista, o qual apresentamos no atual número, intitulado Ensaio teórico pela patrimonializacao do espaço banal. ${ }^{4}$ Eduardo se foi (em matéria) e nos deixou de lembrança esse seu último artigo.

Porém, mais do que essas trocas acadêmicas, tive a oportunidade de dialogar ou estar com Yázigi em muitos momentos, para reconhecê-lo autoral, intenso e desmedido em sua crítica afiada e, simultaneamente, elegante. Não é qualquer pessoa que se dedica a ir ao cinema todos os dias da semana, o que fazia, religiosamente, para alimentar seu conhecimento também nessa área, ao ponto de me comentar, em maio de 2017, por ocasião de um trabalho de campo que realizávamos em Paranapiacaba, SP, que estava terminando um roteiro para um filme. Em nossas conversas, mensagens e e-mails, Yázigi chamava muito minha atenção, pois sempre encontrava motivos para se referir, carinhosamente, a Milton Santos e a Maria Adélia Aparecida de Souza. A esta última, reforçava sua estima falando da "grande amiga Adélia".

Como bem destacou o Departamento de Geografia da Universidade de São Paulo (em nota oficial), Eduardo Yázigi teve uma longa história com aquela instituição. Primeiro, no início dos anos 1960, como aluno do curso de História e, alguns anos mais tarde, como professor da Faculdade de Arquitetura e Urbanismo; a partir da década de 1990, ingressou como docente no Departamento de Geografia da USP. Lembra a nota que seu mestrado e doutorado, ambos orientados pelo geógrafo francês Pierre Monbeig, foram obtidos na Universidade de Paris, cidade onde viveu por mais de dez anos, entre final dos anos 1960 e meados dos anos 1970. Poliglota (falava seis idiomas) e erudito, Yázigi destacou-se nacional e internacionalmente. Ainda, participou de forma intensa e singular na formação de muitos estudantes e pesquisadores, tendo orientado cerca de trinta mestres e doutores, ao longo de sua carreira, perpetuando seu legado intelectual. $^{5}$

Por fim, em fórum mais íntimo, Yázigi era muito atento, delicado e divertido com seus amigos mais próximos. Já sinto falta de suas mensagens e e-mails sarcásticos semanais.

"Saudades do futuro"! Seguramente, nos vemos, companheiro!

\footnotetext{
2 Ver seu texto em http://www.lsie.unb.br/espacoegeografia/index.php/espacoegeografia/article/view/259

${ }^{3}$ Ver seu texto em http://periodicos.unb.br/index.php/revistacenario/article/view/18303

${ }^{4}$ Ver seu texto em http://periodicos.unb.br/index.php/patryter/article/view/14281

${ }^{5}$ Ver a nota na íntegra em https://fflch.usp.br/1155
} 